\title{
PRODUCTIVE PERFORMANCE OF RABBITS FED ON DIETS SUPPLEMENTED WITH SUNFLOWER OIL
}

\author{
W. Elsetiha' ${ }^{1}$;. M. El-Hais ${ }^{1}$; G. E. Younan ${ }^{2}$ and T. El-Rayes ${ }^{1}$ \\ ${ }^{1}$ Animal Production Department, Faculty of Agriculture, Tanta University, Egypt. \\ ${ }^{2}$ Animal Production Research Institute, Agricultural Research Center, Dokki, Giza, Egypt.
}

(Received 12/2 /2019, Accepted 26 /3 /2019)

\section{SUMMARY}

$\mathrm{T}$ he current investigation was conducted to study the effects of dietary supplementation of different sunflower oil levels on productive performance and physiological status of New Zealand White Rabbits. A total of 56 weaned New Zealand White rabbits, 5 weeks of age, was assigned randomly into four similar experimental groups, 14 rabbits in each ( 7 males and 7 females). Rabbits in the first group were served as control (G1), while those in the second, third and 4thgroups were fed diets containing $1 \%(\mathrm{G} 2), 2 \%$ (G3) and 3\% (G4) sunflower oil, respectively, and the experimental period lasted for 8 weeks. Results indicate that all growth performance parameters in G1 and G2, including final LBW and average daily gain were significantly $(\mathrm{P}<0.05)$ higher, while average feed intake was significantly $(\mathrm{P}<0.05)$ lower than in G3 and $\mathrm{G} 4$, being with the best results in G1 and the poorest results in G4. These results reflected significantly $(\mathrm{P}<0.05)$ higher feed conversion ratio and productive index (PI) in G1 and G2 than in G3 and G4, being the highest in G1, but did not differ significantly from that in G2. Concentration of blood serum total proteins and globulins in G4, and glucose concentration in G3 and G4 were significantly $(\mathrm{P}<0.05)$ decreased as compared to G1. Concentration of blood serum total cholesterol, HDL, and triglycerides in G3 and G4 significantly $(\mathrm{P}<0.05)$ increased, while LDL concentration decreased as compared to G1. However, concentration of blood serum albumin and urea as well as serum activity of AST and ALT were not influenced by experimental diets. On the other hand, biochemical parameters in G2 did not differ significantly from that in control one. Sunflower oil at different levels had no significant effects on carcass and dressing percentage (with or without head) of growing rabbits. The same trend was observed for the relative weight of heart, stomach, small intestine, caecum, proximal colon and distal colon. The histological examination revealed normal liver and kidney function in all studied groups. Although rabbits fed the control diet showed the highest net revenue/rabbit, those in G2 fed diet containing $2 \%$ sunflower oil had the highest net revenue/group as a result of the highest viability rate in G2 (14/14) as compared to $(12 / 14)$ in each of G1, G3 and G4. Dietary supplementation of sunflower oil at a level of $1 \%$ showed the highest economic efficiency without adversely effects on growth performance, carcass traits, physiological status, and liver and kidney function of growing rabbits.

Keywords: rabbits, sunflower oil, productivity, lipid profile, histology.

\section{INTRODUCTION}

Rabbit production is being encouraged as a means of improving the daily protein intake of individuals, because its high protein and low cholesterol content (Okonkwo et al., 2008). The New Zealand White (NZW) rabbit is a commercial meat rabbit breed introduced into Egypt to participate in increasing meat production. The NZW rabbits have high fertility, fecundity and prolificacy, and rapid growing. Under the Egyptian conditions, these advantages are affected largely by several factors such as the environmental, management (Yamani et al., 1991) and nutritional conditions (Bhatt and Swain, 2003).

Numerous studies tried to increase productive and reproductive performance of rabbits by using concentrated energetic diets, based on increasing the carbohydrate or fat contents, regardless of the maximal level of starch or minimal level of fiber, which caused to increase digestive disorders especially in young rabbits (Blas and Gidenne, 1998; Gidenne et al., 2005; Bhatt and Swain, 2003). Previous experiments had shown that fat supplementation in diets of growing rabbits decreased feed intake, improved digestible energy 


\section{Elsetiha et al.}

(DE) intake and feed conversion rate (Bhatt and Swain, 2003). Also, nutrients digestibility was increased when fat is included in rabbit diets, that may be due to better emulsion and absorption of unsaturated fatty acids (UFA) in the digestive tract (Casado et al., 2010). Diets with higher amounts of mono-unsaturated (MUFA) or poly-unsaturated fatty acids (PUFA) and lower amount of saturated fatty acids were associated with improving body weight, weight gain, feed intake, feed conversion ratio and mortality percentage (Ahmed, 2013).

Sunflower oil is a MUFA/ PUFA mixture of mostly oleic acid (omega-9)-linoleic acid (omega-6) group of oils. It contains about 30\% oleic acid (mono-unsaturated omega-9) and 59\% linoleic acid (polyunsaturated omega-6) as published in British Pharmacopoeia (2005), which frequently used as a vegetable source of n-6 and n-9 UFA in growing rabbit diets to improve productive performance and produce n-6 and n-9 enriched meat (Aguilera et al., 2002; Zsédely et al., 2008; Casado et al., 2013).

Therefore, the objective of this study was to determine the optimal dietary fat level of sunflower oil, as a supplemented source of $n-6$ and n-9 UFA, in term of studding the productive performance, some physiological parameters and economic efficiency of growing New Zealand White rabbits.

\section{MATERIALS AND METHODS}

\section{Animals and experimental design:}

Fifty-six weaned New Zealand White rabbits, with 5 weeks of age and $633.33 \pm 8.63 \mathrm{~g}$ live body weight, were assigned randomly into four similar experimental groups, 14 rabbits in each ( 7 males and 7 females). All rabbits were kept in community battery cages with 7 replicates ( 2 rabbits per cage), four replicates for each sex in $25 \times 50 \times 35 \mathrm{~cm}$ wire cages, set up in a close rabbit house with suitable ventilation. All rabbits were managed under the same managerial, hygienic and environmental conditions. The experimental period lasted from 5 up to $13 \mathrm{wk}$ of age.

\section{Experimental diets:}

Four experimental diets were formulated to cover the essential nutrient requirements for growing rabbits (De Blas and Mateos, 1998). The $1^{\text {st }}$ group of rabbits was fed a basal diet without sunflower oil $\left(\mathrm{G} 1\right.$, control), while those in the $2^{\text {nd }}(\mathrm{G} 2), 3^{\text {rd }}(\mathrm{G} 3)$ and $4^{\text {th }}(\mathrm{G} 4)$ groups were fed diets supplemented with 1, 2 and $3 \%$ sunflower oil, respectively. Ingredients and chemical composition of the basal diet are shown in Table (1). The basal diet was in pelleted form, and rabbits in all experimental groups were fed ad libitum, while water was available through water nipple in each cage. Diets of treatment groups $(\mathrm{G} 2$, G3 and G4) were supplemented with its level of sunflower oil. Oil was sprayed on a thin layer of the diet (3-4 $\mathrm{cm})$ at the ground. Thereafter the supplemented diet was mixed and packaged in nylon bags in an amount of weekly feeding. Rabbits were fed the tested rations gradually within 7-10 days at the beginning of the feeding period.

\section{Experimental procedures:}

Throughout the feeding period from 5 up to 13 wk of age, LBW and feed intake of rabbits were weekly recorded, then body weight gain, feed conversion ratio and performance index were calculated. Number of dead bunnies throughout the entire length of the experimental period was recorded and mortality rate was calculated. Performance index (PI) was calculated as the following :

$$
\mathrm{PI}=(\text { Final LBW }(\mathrm{kg}) / \text { feed conversion ratio }) \times 100 \text {. }
$$

\section{Blood sampling:}

Blood samples were collected at the end of the experimental period from three male rabbits from each group during slaughter into centrifuge tubes without anticoagulant. After clotting, blood serum was separated by centrifugation of blood samples at $3000 \mathrm{rpm}$ for 15 minutes and kept frozen at $-20^{\circ} \mathrm{C}$ till assayed.

Concentration of blood serum total proteins, albumin, glucose, cholesterol, triglycerides, high density lipoproteins (HDL), low density lipoproteins (LDL), creatinine and urea, activity of aspartate (AST) and alanine (ALT) transaminases as well as concentration of estrogen (E2) and progesterone (P4) were determined. Blood biochemicals were determined spectrophotometrically using commercial specific diagnostic kits (Bio-Merieux, Laboratory Reagents and Products, France). 
Table (1): Ingredients and chemical analysis of the basal diets.

\begin{tabular}{lclc}
\hline Ingredient & $\%$ & Component & $\begin{array}{c}\text { Content } \% \\
\text { on DM basis }\end{array}$ \\
\hline Berseem hay & 32.5 & Dry matter (DM) & 86.05 \\
Barley grain & 22.5 & Crude protein (CP) & 17.43 \\
Yellow corn & 11.5 & Crude fiber (CF) & 13.397 \\
Soybean meal 44\% & 19.4 & Ether extract (EE) & 1.6335 \\
Wheat bran & 10.5 & Ash & 5.40 \\
Sunflower oil & 0 & DE $(\mathrm{kcal} / \mathrm{kg})^{* *}$ & 2463.9 \\
Limestone & 0.5 & ME (kcal/kg)** & 2307.8 \\
Di-Calcium phosphate & 1812.3 & Calcium & 1.22 \\
DL-Methionine & 0.2 & Phosphorus & 0.85 \\
Common salt & 0.3 & Methionine & 0.46 \\
Premix* & 0.3 & Lysine & 0.88 \\
Total & 100 & & Total \\
\hline
\end{tabular}

* Premix: produced by Pestar Company, China. Each $3 \mathrm{Kg}$ vitamin and mineral mixture contain: Vitamin A 12000000 IU, Vit.D3 $2200000 \mathrm{IU}$, Vit. E $10000 \mathrm{mg}$, Vit.K,2000 mg, Vit.B $11000 \mathrm{mg}$, Vit.B24000mg, Vit.B61500mg, Vit.B ${ }_{12} 10 \mathrm{mg}$, Pantothenic Acid 10000mg, Niacin 20000mg, Biotin $50 \mathrm{mg}$, Folic acid 1000mg, Choline chloride 500gm, Selenium $100 \mathrm{mg}$, Manganese 55000mg, Zinc 50000mg, Iodine $1000 \mathrm{mg}$ and carrier CaCO3, to $3000 \mathrm{gm}$.

** DE: Digestible energy and ME: metabolizable energy were calculated according to De Blas and Mateos (1998).

\section{Carcass traits and histological study:}

At the end of the experimental period (13 wk of age), three male rabbits from each group were randomly chosen, fasted for $12 \mathrm{~h}$, weighed and slaughtered to evaluate carcass traits.

Small samples from liver and kidney of slaughtered male rabbits in each group were taken and put in neutral formalin (10\% formalin solution, 38-40\%) for $24-48 \mathrm{~h}$, then washed by tap water for $24 \mathrm{~h}$ and dehydrated in degraded levels of ethyl alcohol (50-100\%), cleared, routinely processed and sectioned by microtome at 5-7 $\mu \mathrm{m}$ thickness. Sections were mounted on glass slides, deparaffinized with xylol, and stained with hematoxylin and eosin for histological examination by a light microscope.

\section{Statistical analysis}

Data of all growth performance parameters, blood serum parameters, carcass traits and economic feed efficiency were statistically analyzed using one-way design. General Linear Model Program (GLM) procedures of SAS (2004) was used, however, Duncan's multiple range tests was performed (Duncan, $1955)$ to test the significant differences among means. All significant differences were set at level of $\mathrm{P}<0.05$. The following statistical model is used to estimate the effects of different levels of sunflower oil:

$$
\mathrm{Y}_{\mathrm{ij}}=\mu+\alpha_{\mathrm{i}}+\mathrm{e}_{\mathrm{ij}}
$$

Where: $Y_{i j}=$ an observations $\mu=$ Overall mean, $\alpha_{i}=$ Effect of sunflower oil level (i=0, 1, 2, and 3\%) and $\mathrm{e}_{\mathrm{ij}}=$ Residual (Random error).

\section{RESULTS AND DISCUSSION}

\section{Growth performance and feed efficiency:}

Results of Table (2) revealed that all growth performance parameters in G1 and G2, including final LBW and average daily gain were significantly $(\mathrm{P}<0.05)$ higher, while average feed intake was significantly $(\mathrm{P}<0.05)$ lower than in G3 and G4, being with the best results in G1 and the poorest results in G4. These results reflected significantly $(\mathrm{P}<0.05)$ higher feed conversion ratio and productive index $(\mathrm{PI})$ in $\mathrm{G} 1$ and $\mathrm{G} 2$ than in G3 and G4, being the highest in G1, but did not differ significantly from that in G2.

Based on these results rabbits in G2 showed higher growth performance parameters as compared to other treatment groups, but superior those in G1 in improving viability rate of rabbits throughout the feeding period. This result is in agreement with Nobakht et al. (2011), who reported that feed intake was increased by addition of sun- flower oil at $4 \%$ in the starter diet of broiler chicks. The decreased feed conversion ration despite increasing level of feed and energy intakes may be due to source of fatty acids in sun-flower oil. In 


\section{Elsetiha et al.}

this respect, several studies have shown that rabbits have the ability to utilize significant amounts of dietary fat as a source of energy; however, the efficiency of its utilization largely depends on the composition of fatty acids. . Bodyyyyyy weight gain of broiler chickens were significantly reduced by dietary conjugated linoleic acid (Szymczyk et al., 2001, Zduńczyk et al., 2001; Shahriar et al., 2007). Sunflower oil has the higher percentage of linoleic acid (C18:2, $\omega-6)$, as omega 6 fatty acids and therefore this plant oil has the lower $\omega-3$ to $\omega-6$ fatty acid ratio in comparison to soybean oils (Jalali et al., 2015).

Table (2): Effect of sunflower inclusion levels on growth performance of growing New Zealand White rabbits from 5 to 13 wks. of age.

\begin{tabular}{|c|c|c|c|c|c|}
\hline \multirow{2}{*}{ Parameter } & \multirow{2}{*}{ G1 (Control) } & \multicolumn{3}{|c|}{ Treatment group } & \multirow{2}{*}{ P-value } \\
\hline & & $\mathrm{G} 2$ & $\mathrm{G} 3$ & G4 & \\
\hline Initial LBW (g) & $631.6 \pm 76.01$ & $633.33 \pm 4.41$ & $632.50 \pm 3.09$ & $633.33 \pm 8.63$ & 0.99 \\
\hline Final LBW $(\mathrm{g})$ & $2211.67 \pm 17.92^{\mathrm{a}}$ & $2191.67 \pm 19.05^{\mathrm{a}}$ & $2108.33 \pm 21.47^{\mathrm{b}}$ & $2044.17 \pm 31.29^{\mathrm{b}}$ & 0.0001 \\
\hline \multicolumn{6}{|c|}{ Average daily weight gain $(\mathrm{g} / \mathrm{h} / \mathrm{d})$ : } \\
\hline 5-9 weeks & $29.91 \pm 0.53$ & $29.43 \pm 0.87$ & $28.63 \pm 1.01$ & $27.59 \pm 0.71$ & 0.21 \\
\hline 9-13 weeks & $26.52 \pm 0.82^{\mathrm{a}}$ & $26.22 \pm 0.56^{\mathrm{a}}$ & $24.08 \pm 1.18^{\mathrm{ab}}$ & $22.79 \pm 0.64^{\mathrm{b}}$ & 0.01 \\
\hline 5-13 weeks & $28.21 \pm 0.26^{\mathrm{a}}$ & $27.83 \pm 0.30^{\mathrm{a}}$ & $26.35 \pm 0.34^{\mathrm{b}}$ & $25.19 \pm 0.54^{\mathrm{c}}$ & 0.0001 \\
\hline \multicolumn{6}{|c|}{ Average daily feed intake $(\mathrm{g} / \mathrm{h} / \mathrm{d})$ : } \\
\hline $5-9$ weeks & $73.93 \pm 1.07^{\mathrm{c}}$ & $75.56 \pm 0.84^{\mathrm{bc}}$ & $77.11 \pm 0.59^{\mathrm{ab}}$ & $78.07 \pm 0.59^{\mathrm{a}}$ & 0.0084 \\
\hline 9-13 weeks & $111.31 \pm 0.54^{\mathrm{c}}$ & $113.66 \pm 1.03^{\mathrm{bc}}$ & $115.59 \pm 0.78^{\mathrm{ab}}$ & $116.82 \pm 1.12^{\mathrm{a}}$ & 0.0018 \\
\hline 5-13 weeks & $92.62 \pm 0.31^{\mathrm{c}}$ & $94.61 \pm 0.84^{\mathrm{bc}}$ & $96.35 \pm 0.65^{\mathrm{ab}}$ & $97.44 \pm 0.85^{\mathrm{a}}$ & 0.0005 \\
\hline \multicolumn{6}{|l|}{ Feed conversion ratio: } \\
\hline 5-9 weeks & $2.48 \pm 0.07^{\mathrm{b}}$ & $2.58 \pm 0.11^{\mathrm{ab}}$ & $2.71 \pm 0.11^{\mathrm{ab}}$ & $2.84 \pm 0.07^{\mathrm{a}}$ & 0.005 \\
\hline 9-13 weeks & $4.22 \pm 0.13^{\mathrm{b}}$ & $4.34 \pm 0.09^{\mathrm{b}}$ & $4.85 \pm 0.20^{\mathrm{a}}$ & $5.14 \pm 0.12^{\mathrm{a}}$ & 0.0005 \\
\hline 5-13 weeks & $3.28 \pm 0.04^{\mathrm{c}}$ & $3.40 \pm 0.06^{\mathrm{c}}$ & $3.66 \pm 0.03^{\mathrm{b}}$ & $3.87 \pm 0.07^{\mathrm{a}}$ & 0.0001 \\
\hline Performance index $(\%)$ & $67.41 \pm 1.27^{\mathrm{a}}$ & $64.55 \pm 1.64 \mathrm{a}$ & $57.68 \pm 1.09^{\mathrm{b}}$ & $52.91 \pm 1.77 \mathrm{c}$ & 0.0001 \\
\hline Viability rate & $85.6(12 / 14)$ & $100(14 / 14)$ & $85.6(12 / 14)$ & $85.6(12 / 14)$ & - \\
\hline
\end{tabular}

Also, Fernandez-Carmona et al. (1998) reported that increasing the level of dietary fat did not increase average daily gain. the poorer performance of rabbits fed the vegetable oil supplemented diets could be due to its negative effects on digestion of other nutrients, such as fiber, with negative consequences on intake and performance. Falcao et al. (1996) showed that the proportion of the volatile fatty acid in caecum content was influenced by the fiber level, fiber source and fat addition to the diet.

\section{Blood serum biochemical parameters:}

Results revealed that, concentration of blood serum total proteins and globulins in G4, and glucose concentration in G3 and G4 were significantly $(\mathrm{P}<0.05)$ decreased as compared to G1. Concentration of total cholesterol, HDL, and triglycerides in G3 and G4 were significantly $(\mathrm{P}<0.05)$ increased, while LDL concentration decreased as compared to G1. However, concentration of serum albumin and urea as well as serum activity of AST and ALT were not influenced by experimental diets. Also, all biochemical parameters in G2 did not differ significantly from that in control one (Table 3).

It is of interest to note that blood serum total proteins concentration of rabbits received diets containing sunflower oil $(3 \%)$ was significantly $(\mathrm{P}<0.05)$ reduced by $8.53 \%$ compared to the control group as a result of significant $(\mathrm{P}<0.05)$ decrease in globulin concentration. Also, concentration of glucose was significantly $(\mathrm{P}<$ 0.01 ) decreased by increasing the level of sunflower oil in the rabbit diets by $16.48,29.38$ and $44.08 \%$ for rabbits fed diet containing 1, 2 or $3 \%$ sunflower oil as compared to control, respectively.

Concentration of blood serum total cholesterol was significantly $(\mathrm{P} \leq 0.05)$ increased in rabbits fed diets containing 1, 2 and 3\% sunflower oil by 31.07, 38.85 and 55.06\% as compared to control, respectively. While, HDL concentration, was significantly $(\mathrm{P}<0.05)$ increased by 25.01 and $34.28 \%$ in rabbits fed diet containing 2 and 3\% sunflower oil as compared to control, respectively. Concentration of LDL was significantly $(\mathrm{P}<0.05)$ decreased by 49.71 and $52.14 \%$ in rabbits fed diet containing 2 and $3 \%$ sunflower oil as compared to control, respectively. Serum triglycerides concentration was significantly $(\mathrm{P}<0.05)$, increased 
by 32.09 and $39.56 \%$ in rabbits fed diet containing 2 and $3 \%$ sunflower oil as compared to control, respectively.

Regarding the hormonal serum profile, concentration of estrogen $(\mathrm{E} 2)$ was significantly $(\mathrm{P}<0.05)$ higher in all treatment groups than in control, being the highest in G4. While serum progesterone (P4) concentration was not affected significantly by sunflower oil (Table 3 ).

Table (3): Effect of sunflower inclusion levels on some blood biochemical parameters of growing New Zealand White rabbits at the end of feeding period

\begin{tabular}{lccccc}
\hline \multirow{2}{*}{ Item } & \multirow{2}{*}{ G1 (Control) $)$} & \multicolumn{3}{c}{ Treatment group } & \multirow{2}{*}{ P-value } \\
\cline { 3 - 5 } & & G2 & G3 & G4 & \\
\hline Total proteins (g/dl) & $6.33 \pm 0.13^{\mathrm{a}}$ & $6.21 \pm 0.03^{\mathrm{a}}$ & $6.08 \pm 0.09^{\mathrm{ab}}$ & $5.79 \pm 0.14^{\mathrm{b}}$ & 0.03 \\
Albumin (g/dl) & $3.17 \pm 0.06$ & $3.18 \pm 0.09$ & $3.05 \pm 0.23$ & $2.97 \pm 0.07$ & 0.66 \\
Globulin (g/dl) & $3.16 \pm 0.09^{\mathrm{a}}$ & $3.03 \pm 0.06^{\mathrm{ab}}$ & $3.03 \pm 0.12^{\mathrm{ab}}$ & $2.82 \pm 0.11^{\mathrm{b}}$ & 0.03 \\
Glucose (mg/dl) & $93.00 \pm 6.43^{\mathrm{a}}$ & $77.67 \pm 4.26^{\mathrm{ab}}$ & $65.67 \pm 4.91^{\mathrm{bc}}$ & $52.00 \pm 4.51^{\mathrm{c}}$ & 0.002 \\
Urea (mg/dl) & $30.12 \pm 29.40$ & $29.83 \pm 0.68$ & $29.00 \pm 2.20$ & $28.70 \pm 2.57$ & 0.98 \\
Total cholesterol (mg/dl) & $98.67 \pm 4.67^{\mathrm{c}}$ & $129.33 \pm 8.99^{\mathrm{b}}$ & $137.00 \pm 2.52^{\mathrm{ab}}$ & $153.00 \pm 2.31^{\mathrm{a}}$ & 0.0006 \\
HDL (mg/dl) & $55.33 \pm 2.55^{\mathrm{b}}$ & $66.77 \pm 5.04^{\mathrm{ab}}$ & $69.17 \pm 3.14^{\mathrm{a}}$ & $74.30 \pm 3.12^{\mathrm{a}}$ & 0.03 \\
LDL (mg/dl) & $46.87 \pm 1.39^{\mathrm{a}}$ & $39.43 \pm 2.64^{\mathrm{a}}$ & $23.57 \pm 3.09^{\mathrm{b}}$ & $22.43 \pm 2.13^{\mathrm{b}}$ & 0.0002 \\
Triglycerides (mg/dl) & $89.33 \pm 1.45^{\mathrm{b}}$ & $102.33 \pm 5.36^{\mathrm{b}}$ & $118.00 \pm 3.79^{\mathrm{a}}$ & $124.67 \pm 6.06^{\mathrm{a}}$ & 0.002 \\
AST (U/L) & $64.33 \pm 3.84$ & $68.33 \pm 8.69$ & $68.00 \pm 9.02$ & $67.33 \pm 4.09$ & 0.97 \\
ALT (U/L) & $43.67 \pm 3.18$ & $44.33 \pm 1.20$ & $45.00 \pm 2.08$ & $46.33 \pm 2.33$ & 0.86 \\
Estrogen (E2) (ng/ml) & $19.70 \pm 0.31^{\mathrm{c}}$ & $23.80 \pm 1.11^{\mathrm{b}}$ & $27.97 \pm 0.69^{\mathrm{a}}$ & $30.03 \pm 0.29^{\mathrm{a}}$ & 0.0001 \\
Progesterone (P4) (ng/ml) & $0.37 \pm 0.04$ & $0.36 \pm 0.02$ & $0.35 \pm 0.11$ & $0.34 \pm 0.02$ & 0.97 \\
\hline
\end{tabular}

$a, b$ and $c:$ Means in the same row with different superscripts are significantly different $(P \leq 0.05)$.

Any change in the concentration of blood serum protein and albumin indicate a change in the normal liver functions (Ahmed et al., 1992). Generally, the level and source of fats in the diet have important effects on plasma lipid profile in different animal species. This rule is evident in this study, which showed that, dietary sunflower oil caused an increase in all lipid profiles examined, except LDL concentration. In this respect, many authors found that high fat-fed rabbits showed an increase in plasma levels of total cholesterol and triglycerides as well as visceral adipose tissue accumulation (Zheng et al., 2009; Tuncer et al., 2009). In another study, the addition of dietary fat from animal and vegetable sources increased total cholesterol and triglycerides in rats (Pandev and Kumar, 2012). Also, Elrufai et al. (2015) reported that rabbits fed diet modulated of extra 7\% sunflower oil significantly increased all lipid profiles. However, Fekete et al. (1990) found no effects of supplemental oil on lipid profile.

The enzymatic activity of ALT and AST revealed normal liver function (Obi et al., 2004). ALT levels were increased only in those rats fed palm oil and groundnut oil- based diets compared with the control, while AST levels was increased only in those rats administered coconut oil-based diet.

\section{Carcass traits:}

Data of Table (4) showed that, dietary sunflower oil at different levels had no significant effects on carcass and dressing percentage (with or without head) of growing rabbits. The same trend was observed for the relative weight of heart, stomach, small intestine, caecum, proximal colon and distal colon.

On the other hand, the relative liver weight was significantly $(\mathrm{P} \leq 0.05)$ increased by 13.39 and $18.66 \%$ for rabbits fed diet containing 2 and 3\% sunflower oil as compared to control, respectively. While, the same groups had significantly $(\mathrm{P} \leq 0.05)$ lower relative spleen weight by 35.04 and $33.33 \%$ as compared to control. The relative kidney weight significantly $(\mathrm{P} \leq 0.05)$ decreased by $11.88 \%$ for rabbits fed diet containing $3 \%$ sunflower oil compared to control. No significant differences were observed between other experimental groups in relative kidney weight.

In addition, the relative weights of giblets, gastrointestinal tract and kidney fat were significantly $(\mathrm{P} \leq 0.05)$ increased by increasing sunflower oil level in growing rabbit diets. Whereas, rabbits fed diet 


\section{Elsetiha et al.}

containing 3\% sunflower oil had significantly $(\mathrm{P} \leq 0.05)$ the highest relative weights of giblets, gastrointestinal tract and kidney fat by $9.25,11.78$ and $86.81 \%$ as compared to control group, respectively, with no significant differences among other treatments.

Dietary oil supplementation was found to have a significant effect on carcass fatness. Fat deposition in the body is affected by the degree of saturation of dietary fatty acids. Low saturated fats can have an effect on lower fatness. Low fatness may also result from the stimulating effect of polyunsaturated acids on enzymes that degrade fatty acids ( $\beta$-oxidation) as reported by Abo Omar and Zaza (2015). In compatible with the present results, Ahmad et al. (2007) reported an increased organ weight, which is consistent with low LBW. In addition, Fernandez and Fraga (1996) reported no medication of the dressing percentage according to the dietary fat level in rabbits. On the other hand, Pla and Cervera (1997) reported that vegetal fat and animal fat enriched diets significant increased dressing yield in rabbits. Also, Nobakht et al. (2011) showed that sunflower, soybean, and canola oils and their combination with a chick's diet had no effect on the relative weight of the bird's liver.

Table (4). Effect of sunflower inclusion levels on carcass traits of growing New Zealand White rabbits from 5 to 13 wks. of age.

\begin{tabular}{|c|c|c|c|c|c|}
\hline \multirow{2}{*}{ Carcass trait } & \multirow{2}{*}{$\begin{array}{c}\text { G1 } \\
\text { (Control) }\end{array}$} & \multicolumn{3}{|c|}{ Treatment group } & \multirow{2}{*}{ P-value } \\
\hline & & G2 & G3 & G4 & \\
\hline \multicolumn{6}{|l|}{ Dressing percentage: } \\
\hline With head & $61.84 \pm 0.03$ & $61.49 \pm 0.51$ & $61.27 \pm 0.31$ & $61.06 \pm 0.47$ & 0.54 \\
\hline Without head & $56.84 \pm 0.03$ & $56.49 \pm 0.51$ & $56.27 \pm 0.31$ & $56.06 \pm 0.47$ & 0.54 \\
\hline Net carcass & $53.06 \pm 0.09$ & $52.53 \pm 0.43$ & $52.23 \pm 0.27$ & $51.93 \pm 0.49$ & 0.22 \\
\hline \multicolumn{6}{|c|}{ Relative weight of carcass organs $(\%)$ : } \\
\hline Spleen & $1.17 \pm 0.07^{\mathrm{a}}$ & $0.81 \pm 0.11^{\mathrm{b}}$ & $0.76 \pm 0.01^{\mathrm{b}}$ & $0.78 \pm 0.05^{\mathrm{b}}$ & 0.01 \\
\hline Liver & $2.09 \pm 0.03^{\mathrm{b}}$ & $2.27 \pm 0.12^{\mathrm{ab}}$ & $2.37 \pm 0.05^{\mathrm{a}}$ & $2.48 \pm 0.07^{\mathrm{a}}$ & 0.03 \\
\hline Heart & $0.67 \pm 0.04$ & $0.72 \pm 0.03$ & $0.75 \pm 0.00$ & $0.75 \pm 0.08$ & 0.17 \\
\hline Kidney & $1.01 \pm 0.04^{\mathrm{a}}$ & $0.97 \pm 0.02^{\mathrm{ab}}$ & $0.91 \pm 0.03^{\mathrm{ab}}$ & $0.89 \pm 0.03^{b}$ & 0.02 \\
\hline Giblets & $3.78 \pm 0.09^{b}$ & $3.96 \pm 0.15^{\mathrm{ab}}$ & $4.03 \pm 0.05^{\mathrm{ab}}$ & $4.13 \pm 0.07^{\mathrm{a}}$ & 0.04 \\
\hline Kidney fat & $0.91 \pm 0.01^{\mathrm{d}}$ & $1.19 \pm 0.03^{\mathrm{c}}$ & $1.41 \pm 0.07^{\mathrm{b}}$ & $1.70 \pm 0.10^{\mathrm{a}}$ & 0.002 \\
\hline Gastrointestinal tract (GIT) & $19.26 \pm 0.19^{c}$ & $19.96 \pm 0.32^{\mathrm{bc}}$ & $20.74 \pm 0.36^{\mathrm{ab}}$ & $21.53 \pm 0.19^{a}$ & 0.002 \\
\hline
\end{tabular}

\section{Histological study:}

The histological examination of liver of slaughtered rabbits (Fig. 1) revealed normal architecture of the hepatic lobules in treated groups $(\mathrm{G} 2, \mathrm{G} 3$ and $\mathrm{G} 4)$ as in the control group (G1). However, no pathological lesions were observed in liver of rabbits in treated groups as compared to the control one. In all group, the hepatic vein was located in the center of each hepatic lobule with different lumens and shapes. Cellular cord of hepatocytes was radiated around each central hepatic vein. In addition, marked blood sinusoids were arranged in between the hepatocyte's cords. (Fig . 1).

It is worth noting that the observed normal histological structure of liver in all groups was in association with results of the activity of AST and ALT in blood serum of rabbits in in all groups (Table 3), being within the normal range of AST and ALT activities in growing rabbits (Hassan, 2009).

The histological examination of kidneys of slaughtered rabbits (Fig. 2) revealed normal architecture of the renal cortex and medulla in all groups. The renal cortex showed intact glomerular structure of Malpigian corpuscles and normal arrangement of cortical stroma (Fig. 2) in all groups Interestingly, the observe that the similarity in histological structure of kidney in all groups was associated with the normal range of urea in blood serum of rabbits in all groups (Table 3 ). 
Fig 1: The histological examination of liver of slaughtered rabbits

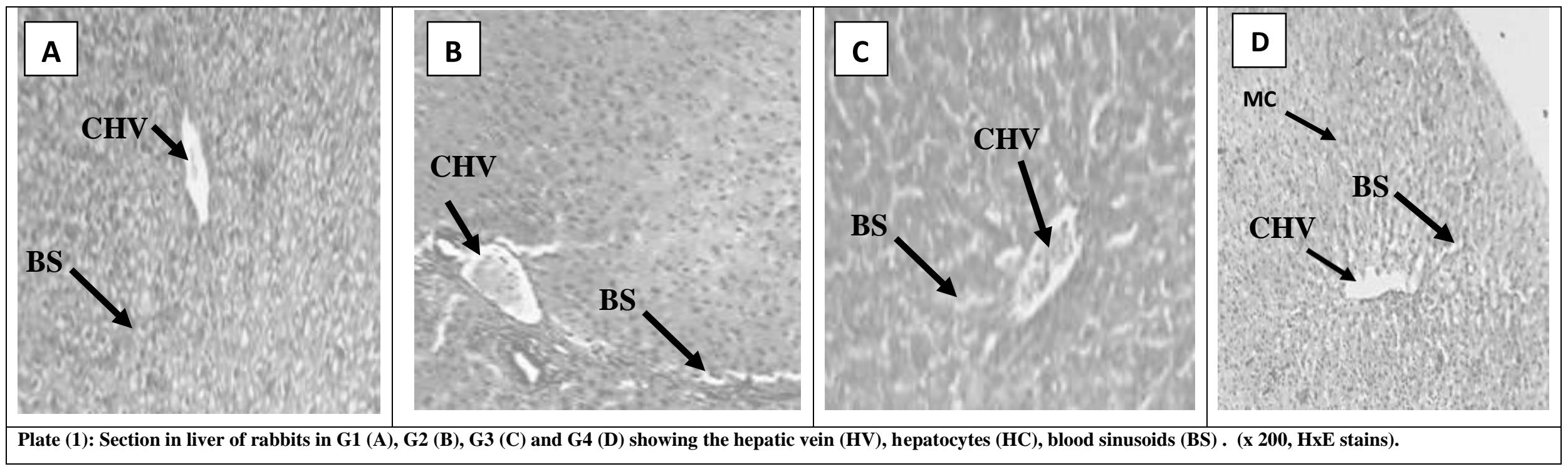


Fig 2: The histological examination of kidneys of slaughtered rabbits
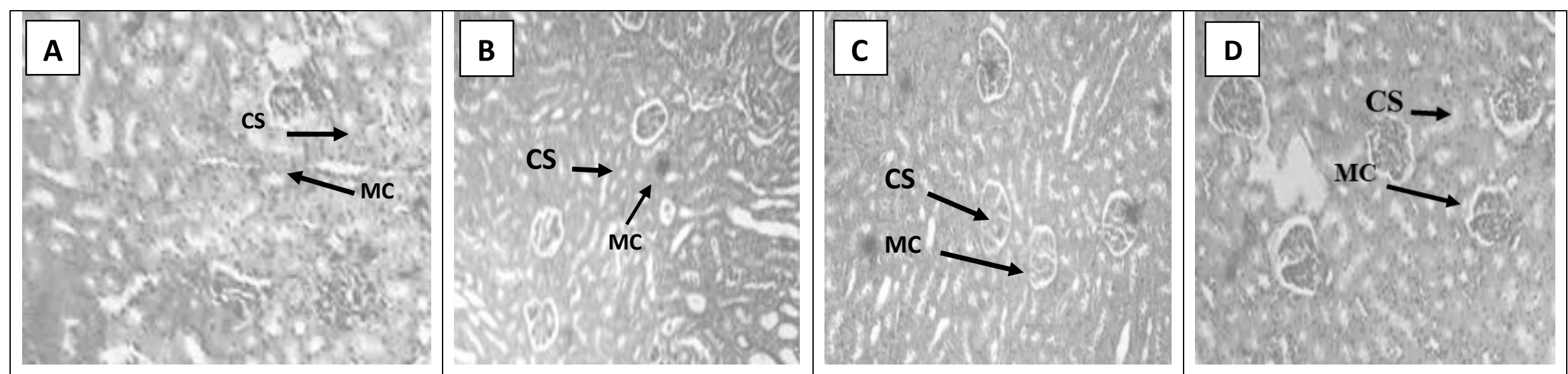

Plate (2): Section in kidney of rabbits in G1 (A), G2 (B), G3 (C) and G4 (D) showing the normal architecture of the renal cortex with normal arrangement of cortical stroma (CS) and Malpigian corpuscles (MC). (x 200, H \& E stains) 


\section{Economic efficiency:}

Although rabbits fed the control diet showed the highest net revenue/rabbit, those in G2 fed diet containing $2 \%$ sunflower oil had the highest net revenue/group as a result of the highest viability rate in G2 (14/14) as compared to (12/14) in each of G1, G3 and G4 (Table 5).

Table (5). Effect of sunflower inclusion levels on economic efficiency of growing New Zealand White rabbits.

\begin{tabular}{lcccc}
\hline \multirow{2}{*}{ Item } & \multirow{2}{*}{ Control } & \multicolumn{3}{c}{ Sunflower oil level (\%) } \\
\cline { 3 - 5 } & & 1 & 2 & 3 \\
\hline Average feed intake (kg /head) & 5.18 & 5.298 & 5.39 & 5.456 \\
Price /kg diet (L.E.) & 4.46 & 4.68 & 4.9 & 5.12 \\
Total feed cost (L.E.) & 23.1028 & 24.79464 & 26.411 & 27.93472 \\
Average weight gain (kg/head) & 1.58 & 1.56 & 1.48 & 1.41 \\
Selling price (L.E.) & 53.72 & 53.04 & 50.32 & 47.94 \\
Net revenue (L.E.)/rabbit & 30.6172 & 28.24536 & 23.909 & 20.00528 \\
Net revenue (L.E.)/group & 367.4064 & 395.43504 & 286.908 & 240.06336 \\
\hline
\end{tabular}

Cost of $\mathrm{kg}$ sunflower oil was 22 L.E. Price of kg live body weight was 34 L.E.

\section{CONCLUSION}

From the economical point of view, the present study concluded that dietary supplementation of sunflower oil at a level of $1 \%$ showed the highest economic efficiency without adversely effects on growth performance, carcass traits, physiological status, and liver and kidney function of growing rabbits.

\section{REFERENCES}

Abo Omar, J. and A. Zaza (2015). Performance and Carcass Characteristics of Rabbits Fed Oil Supplemented Diets. Walailak J Sci \& Tech 2016; 13(2): 93-100.

Aguilera, C. M.; M. C. Ramirez-Tortosa; M. Mesa; C. L. Ramirez Tortosab and A. Gila (2002).Sunflower, virgin-olive and fish oils differentially affect the progression of aortic lesions in rabbits with experimental atherosclerosis. Atherosclerosis., 162:335-344.

Ahmad, N.; S. Majumder; M.A. Miah and M.J. Uddin (2007). Effects of edible fats and oils on the body weight gain and on weights of some selected organs in rats removing the impact of unequal feed intake. Bangladesh Journal Veterinary Medicine, 5 (1\&2): 107-110.

Ahmed, E. (2013). Productive performance of New Zealand White rabbits fed diet containing different levels of Omega -3 fatty acids. Thesis Ph.D., Tanta University.

Ahmed, M.; M.A. Saeed; H. Alam and Z. Ashgar (1992). Biological Studies of indigenous medicinal plants II: Effects of AplotaxislappaDcne. On various parameters of liver metabolism in rabbits. Journal of Islamic Academy of Science, 5:51-56.

Bhatt, R.S. and N. Swain (2003). Effect of graded level of fat supplementation on the growth performance in the rabbits. World Rabbit Science, 11 (1):33-40.

Blas, E.; and T. Gidenne (1998). Digestion of starch and sugars. In: de Blas, C. Wiseman, J. (Eds.), The Nutrition of th rabbit. CABI Publishing, 17-38.

British Pharmacopoeia Commission (2005). "Ph. Eur. monograph 1371". British Pharmacopoeia. Norwich, England: The Stationery Office. ISBN 0-11-322682-9.

Casado, C.; V.J. Moya; J.J. Pascual; E. Blas and C. Cervera (2013). Dietary fatty acid profile: effects on caecal fermentation and performance of young and fattening rabbits. World Rabbit Sci., 21: 235-242. 


\section{Elsetiha et al.}

Casado, C.; V.J. Moya; C. Fernandez; J.J. Pascual; E. Blas and C. Cervera (2010). Diet digestibility in growing rabbits: Effect of origin and oxidation level of dietary fat and vitamin E supplementation. World Rabbit Sci., 18: 57-63.

De Blas, J.C. and G.G. Mateos (1998). Feed formulation. In: The Nutrition of the Rabbit. (De Blas and J. Wiseman Eds) Walling ford, CABI Publ., UK. Chapter, 13:241-254.

Duncan, D.B. (1955). Multiple ranges and multiple f-test, Biometries 11:1-42.

Elrufai, S.; H.E. Mohamed; M.E.S. Barri and F. Elsammani (2015). The effects of fat sources on lipid profile in New Zealand rabbits. International Journal of Agricultural Science Research. 4(2), pp. 035038.

Falcao-E-Cunha, L.; J. Freire and A. Goncalves (1996). Effect of fat level and fiber nature on performances, digestibility, nitrogen balance and digestive organs in growing rabbits. In: Proc. $6^{\text {th }}$ World Rabbit Congress, Toulouse, France, 157-162.

Fekete, S.; I. Hullár; H. Fébel and J. Bokori (1990). The effect of animal fat and vegetable oil supplementation of feeds of different energy concentration upon the digestibility of nutrients and some blood parameters in rabbits. Acta Vet Hung., 38(3):165-75.

Fernandez-Carmona, J. and M. J. Fraga (1996). The effect of dietary fat inclusion on growth, carcass characteristics and chemical composition of rabbits. J. Anim. Sci., 74:2088-2094.

Fernandez-Carmona, J.; F. Bernat; C. Cervera and J.J. Pascual (1998). High lucerne diets for growing rabbits. World Rabbit Science, 6 (2): 237-242.

Gidenne, T.; M. Segura and A. Lapanouse (2005). Effect of cereal sources and processing in diets for the growing rabbit. I. Effects on digestion and fermentative activity in the caecum. Anim. Res., 54: 55-64.

Hassan, A.M. (2009). Effect of boldenoneundecy lenate treatment on buffalo male calf performance. M. SC. Thesis, Faculty of Agric., Menoufiya University

Jalali, S.M.A.; R. Rabiei and F. Kheiri (2015). Effects of dietary soybean and sunflower oils with and without L-carnitine supplementation on growth performance and blood biochemical parameters of broiler chicks. Arch. Anim. Breed., 58, 387-394.

Nobakht, A.; S. Tabatbaei and S. Khodaei (2011). Effects of different sources and levels of vegetable oils on performance, carcass traits and accumulation of vitamine in breast meat of broilers, Curr. Res. J. Biol. Sci, 3, 601-605.

Obi, E.; O.E. Orisakwe; L.A. Asomugha and O.O. Udemezue (2004). The hepatotoxic effect of halofantrine in guinea pigs. Indian Journal of Pharmaceutical Sciences, 36(5):303-305.

Okonkwo, A.C.; Isaac, L.J.; Solomon, I.P. and Eyoh, G.D. (2008). Effects of dietary cassava leaf meal on growth performance of wiener rabbits. Proceedings of $32^{\text {nd }}$ annual conference of Nigeria Society of animal production 32:142-144.

Pandev, R. and N. Kumar (2012). Impacts of high dietary fat on serum cholesterol and development of fatty liver in rats. IJPSR., 3(9): 3175-3178.

Pla, M. and C. Cervera (1997). Carcass and meat quality of rabbits given diets having a high level of vegetable or animal fat. Anim. Sci. 65:299-303.

SAS Institute, (2004). SAS/STAT User's Guide. Relaase Version 7.00. SAS Institute Inc.,. Cary. North Carolina.

Shahriar, H.A.; A. Rezaei; A. Lak and A. Ahmadzadeh (2007). Effect of dietary fat sources on blood and tissue biochemical factors of broiler. J. Anim. Vet. Adv. 2007; 6, 1304-7.

Szymczyk, B.; P.M. Pisulewski; W. Szczurek and P. Hanczakowski (2001). Effects of conjugated linoleic acid on growth performance, feed conversion efficiency, and subsequent carcass quality in broiler chickens. Br. J. Nutr. 85: 465-73.

Tuncer, M.A.; B. Yaymaci; L. Sati; S. Cayli; G. Acar; T. Altug and R. Demir (2009). Influence of Tribulus terrestris extract on lipid profile and endothelial structure in developing atherosclerotic lesions in the aorta of rabbits on a highcholesterol diet. Acta Histochem., 111(6):488-500. 
Yamani, K.A.O.; A.H. Daader; A.A. Askar (1991). Effect of remitting interval on the performance of rabbit production and reproduction. In :Rouvier R. (ed.), BaselgaM. (ed.). Rabbit production and genetics in the Mediterranean area. Zaragoza : CIHEAM,173-178.

Zduńczyk, Z.; J. Jankowski and A. Koncicki (2001). Fats in Poultry Feeding. Selected Problems (in Polish). University of Warmia and Mazury, Olsztyn, Poland, p. 1-85.

Zheng, H.; C. Zhang; W. Yang;, Y. Wang; Y. Lin; P. Yang; Q. Yu; J. Fan and E. Liu (2009). Fat and cholesterol diet induced lipid metabolic disorders and insulin resistance in rabbit. Exp Clin. Endocrinol. Diabetes., 117(8): 400-405.

Zsédely, E.; T. Tóth; C.S. Eiban; G.Y. Virág; J. Fábián and J. Schmidt (2008). Effect of dietary vegetable oil (sunflower, linseed) and vitamin E supplementation on the fatty acid composition, oxidative stability and quality of rabbit meat. In: Proc. of $9^{\text {th }}$ World Rabbit Congress, Verona, Italy,1473-1477.

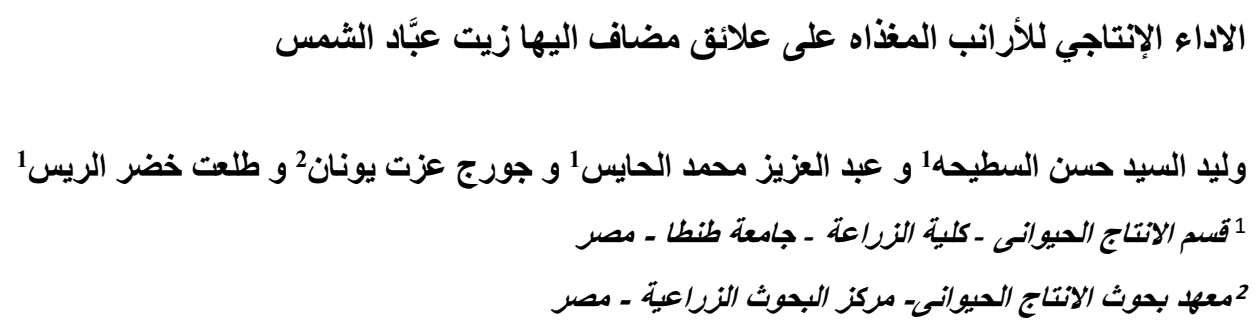

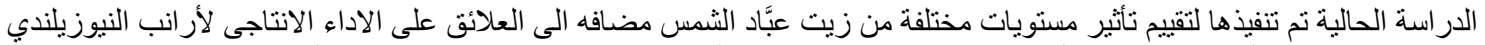

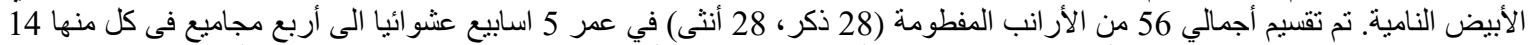

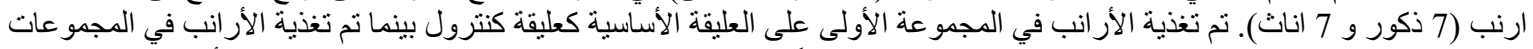

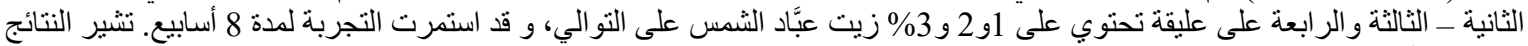

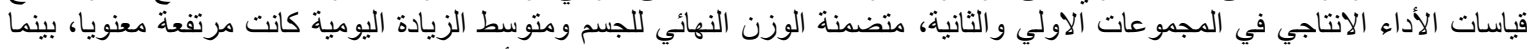

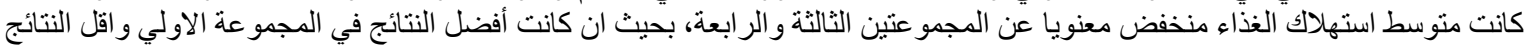

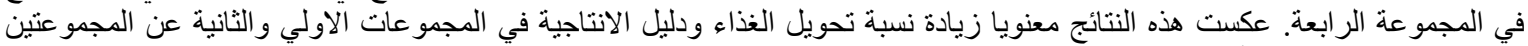

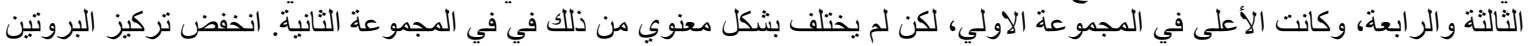

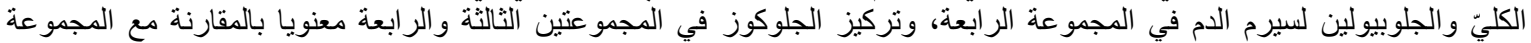

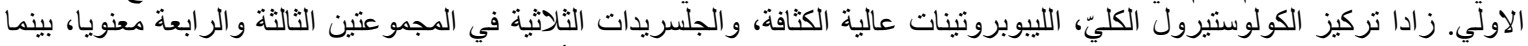

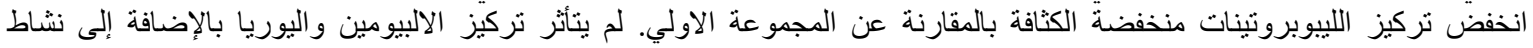

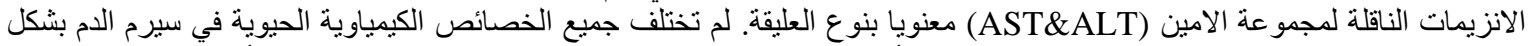

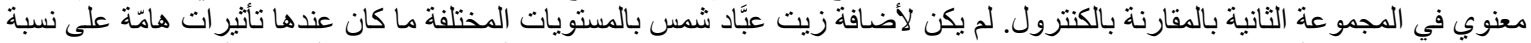

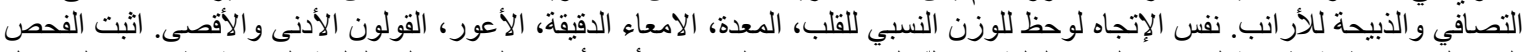

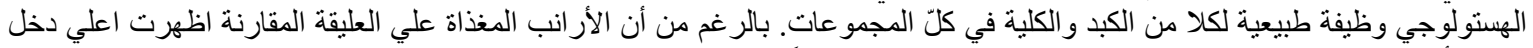

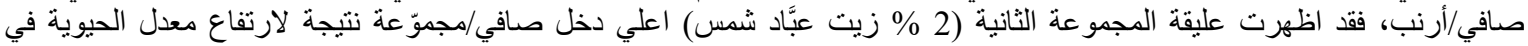
المجمو عة الثانية (14/14) بالمقارنة مع (14/12) في باقي المجمة المعو عات.

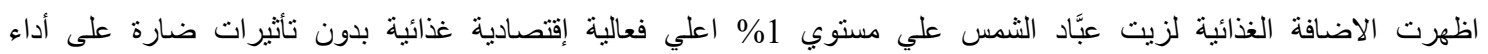

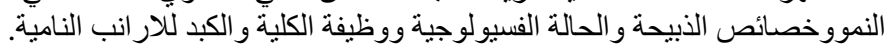

